$\mathbb{T}$ Periodica Polytechnica

Social and Management

Sciences

24(2), pp. 113-118, 2016

DOI: $10.3311 /$ PPso. 8486

Creative Commons Attribution (i)

RESEARCH ARTICLE

\section{Analysis of Tax Education in a Business School: a Case Study}

\author{
Beáta Blechová1, Šárka Sobotovičová1*
}

Received 10 August 2015; accepted after revision 25 November 2015

\begin{abstract}
Tax legislation affects the business and social environment in the Czech Republic significantly. Therefore, the objective of the School of Business Administration in Karviná is to provide students with key information concerning taxes and tax policy of the state within their courses. Emphasis is put on theoretical knowledge and its practical application including the advancement in the field of direct and indirect taxes. Frequent changes in tax legislation and the state's approach to tax policy particularly are one of the fundamental teaching specifics in this area. Specificity of teaching taxes and tax policy consists in linking academic education with vocational one. The article follows up the research on the level of tax education of university students. The objective of the research is to determine and verify the extent to which teaching subjects, dealing with tax issues, affects the level of students' knowledge in connection with a chosen type of studies.
\end{abstract}

\section{Keywords}

education, knowledge, tax literacy, taxation

\footnotetext{
${ }^{1}$ Department of Finance and Accounting, School of Business Administration in Karvina, Silesian University in Opava,

Univerzitní náměstí 1934/3, 73340 Karviná, Czech Republic

${ }^{*}$ Corresponding author, e-mail: sobotovicova@opf.slu.cz
}

\section{Introduction}

Tax issues, including macroeconomic aspects, contribute significantly to financial resources of individuals and households, and have a considerable impact on cash flows in private finances. Basic knowledge of the tax system and the role of taxes in a civil society must be understood as an element to ensure responsible citizens' behaviour towards the family and the state (Janoušková and Sobotovičová, 2013a).

Tax education is an integral part of financial literacy. In the Czech Republic, the government issued a resolution in 2005 which defines the task to develop a system of financial education in primary and secondary schools. Financial literacy was defined in the Czech Republic in 2006 within the activities of an interagency working group for financial education as a set of knowledge and skills. They enable a person to understand finance and handle it properly in different life situations.

An expert group on financial education was established within the European Union based on the Commission decision of April 30, 2008. Nonetheless, systems of financial education in individual EU countries differ markedly. In 2003, the OECD developed the Project of financial education. The National Strategy for Financial Literacy has also existed in the USA since 2003. The importance of education to improve financial literacy in Indonesia in their study deal Hadi et al. (2015).

According to Tokarčíková et al. (2015), universities as education centres play an important role in education and its application. They are not just institutions of higher education and research granting titles but they educate responsible people with excellent knowledge, who are able to solve problems globally and share their knowledge, which the wider community can benefit from.

The competence of efficiency utility of knowledge and skills are the basis for a new economy. Firms and the society need highly competent workers (Kucharčíková, 2014). The effects of improvements in the quality of higher education on the labour market outcomes of highly-educated individual researched in their study Boccanfuso et al. (2015).

Financial literacy has become an important focus not only for government, but also the education and community sectors, the broader finance industry and financial advisers (Chardon, 2014). 
Yilmaz (2011) and Disney and Gathergood (2013) assert that financial education is an important part of people's daily lives. Financial literacy is an important theme in the world's economic and financial interest. An improvement of financial literacy is achieved through financial education Kindle (2010).

The very principle of financial education and literacy, moreover, stumbles on the fact that various financial instruments have become unusually complicated, some of them not precisely understood even by people generally considered experts in the field (Paseková et al., 2013).

For example, Gillen and Loeffler (2012) are also engaged in the issue of increasing financial and tax literacy in the context of teaching at universities.

Financially and fiscally literate citizen is well versed in the issue of money and prices and is able to manage personal/family budget responsibly, including the management of financial assets and liabilities with regard to changing life situations (Janoušková, 2011). Financial literacy as the management of personal or family finances involves three components:

- monetary literacy,

- price literacy,

- budget literacy.

Budget literacy represents an ability to understand important terms such as public finance which include state budget and municipal budgets, incomes and budget expense, taxes, deficit management and budget policy (Vybíhal, 2011).

As Csongor states (2011), it is possible to recognize the predictable situations but also non-predictable ones in our lives, and therefore, a financially literate person is able to estimate the extent of possible financial risks and make the right decisions. The importance of lifelong learning in their work deal Hammer et al. (2012).

An integral and significant part of financial literacy is the area of taxes. This is especially because of the fact that they contribute to financial resources of individuals and households substantially and have an important impact on cash flows in private finances. Taxes represent an issue that every citizen has to face on a daily basis because indirect taxes are included in prices for a final consumer, and income taxes relate both to employed citizens and entrepreneurs (Janoušková and Sobotovičová, 2013). Basic knowledge of the tax system and the role of taxes in a civil society must be understood as an element to ensure responsible citizens' behaviour towards the family and the state (Blechová and Sobotovičová, 2013). Every citizen should have a basic knowledge of the tax system and taxes which are collected in the country where they live. For example, Kamaluddin and Madi (2005) or Madi et al. (2010) dealt with the issue of an assessment of the tax literacy level. Object of their investigation was the level of tax literacy among taxpayers in two Malaysian regions (Sabah and Sarawak). In his study, Barjoyai (1992) was concerned with the importance of tax education in the context of universal knowledge in order to help each citizen with potential liability of paying tax. Tax education enables to understand the tax system well. Eriksen and Fallan (1996) believed that with reasonable understanding of the tax laws, people are willing to respect the tax system. Consequently, they are more compliant to pay tax instead of evading it. Natrah (2014) provided study, which investigate taxpayers' view on their level of tax knowledge, perceived complexity of the income tax systems and the underlying reasons of non-compliance behaviour in New Zealand. From the interviews, taxpayers appeared to have inadequate knowledge on the technical aspects of the income tax system.

Tax systems were also perceived as inherently complex. There are a number of Acts involve in complying with the income tax obligation. However, next big problem seems to be very frequent amendments to the tax legislation. They cause confusion and complexity of the tax system contrary to a principle that taxes should be clear and simple (Blechová, 2012). Changes in tax laws, which are frequent and occur several times a year, mean that achieving and maintaining basic tax literacy principally is almost impossible.

\section{Research objective and used methods}

The primary goal of our research was to find out what the tax knowledge is in case of admitted students to full-time studies in the college compared to part-time (extramural) students who have professional experience. The null hypothesis H0 was determined: The level of students' input knowledge concerning tax issues does not depend on the form of study.

Another phase of the research aimed at assessing full-time and extramural students' level of knowledge after completing courses dealing with tax issues. Statistical significance was determined by changes in students' average scores in Bachelor and Follow-up Masters levels, both full-time and part-time forms of study.

Department of Finance and Accounting of the School of Business Administration in Karviná at the Silesian University in Opava guarantee nine courses dealing with tax issues. They are: Taxes and Taxation Policy of the Czech Republic, Taxes and Taxation Policy A, Taxes and Taxation Policy B, Taxes and Taxation of the European Union, Accounting and Taxes Workshop, Tax Law Application, Entrepreneur's Tax Record, Consumption Taxation, and Property and Consumption Taxation.

During their studies, students are gradually introduced to key information in the field of direct and indirect taxes, the state tax policy including specific taxes in the tax system of the Czech Republic. But they are also introduced to a tax context of the Czech Republic's involvement into international economic structures and harmonization of Czech legal norms with EU standards defining the tax issue.

To determine whether there is a significant difference in students' knowledge depending on the form of study, the 
chi-square test was used. It is a statistical method for determining a strong demonstrable relationship between two variables (Ramík et al., 2005).

A contingency table was created, based on observed and expected frequencies which were calculated according to the following formula (1):

$$
E_{i j}=\frac{n_{i}}{n} \cdot \frac{n_{j}}{n} \cdot n=\frac{n_{i} n_{j}}{n}
$$

where: $n_{i}$ is the sum of individual lines

$n_{j}$ is the sum of individual columns in the contingency table $n$ is the sum of all observed frequencies

The test criterion was calculated using the formula (2):

$$
T=\sum_{i=1}^{2} \sum_{j=1}^{s} \frac{\left(O_{i j}-E_{i j}\right)^{2}}{E_{i j}},
$$

where $s$ means the number of categories of a monitored variable.

Critical value $K=\chi_{\alpha}(s-1)$ of chi-squared distribution with a degree of freedom $\mathrm{df}=\mathrm{s}-1$ was calculated using Excel and the function CHIINV $\alpha$; df) for the given level of significance $\alpha$ 0.05 (Ramík and Perzina, 2014).

To verify the accuracy, significance (p-value) was calculated and was compared with the chosen significance level $(\alpha=0.05)$. The function CHIDIST (T; df) was used for the p-value calculation.

To determine the statistical significance of differences with observed groups of students, average results were calculated first and variability of the results was compared.

Weighted arithmetic average was calculated using the formula (3):

$$
\bar{x}_{w}=\frac{1}{\sum_{i=1}^{n} w_{i}} \sum_{i=1}^{n} w_{i} x_{i}
$$

where: $w_{i}$ are weights

$n$ is the sum of dates.

Sample variance was calculated using the formula (4):

$$
s^{2}=\frac{1}{n-1} \sum_{i=1}^{n}\left(x_{i}-\bar{x}\right)^{2}=\frac{\sum_{i=1}^{n} x_{i}^{2}-n \bar{x}^{2}}{n-1},
$$

where $n-1$ is called the number of degrees of freedom.

To determine whether the results of the given students' group are statistically significant better, the two-sample t-tests assuming equal and unequal variances were used. F-test for the null hypothesis that two normal populations have the same variance was used and the same variance was verified according to the formula:

$$
T=\frac{s_{1}^{2}}{s_{2}^{2}}
$$

The test criterion of the two-sample t-test assuming equal variances was calculated according to the formula:

$$
T=\frac{\bar{X}_{1}-\bar{X}_{2}}{\sqrt{\left(n_{1}-1\right) S_{1}^{2}+\left(n_{2}-1\right) S_{2}^{2}}} \cdot \sqrt{\frac{n_{1} \cdot n_{2} \cdot\left(n_{1}+n_{2}-2\right)}{n_{1}+n_{2}}},
$$

Where $\bar{X}_{1}, \bar{X}_{2}$ are sample means,

$S_{1}^{2}, S_{2}^{2}$ are sample variances,

$n_{1}, n_{2}$ are ranges of 1 st and 2 nd sample.

Critical value $\mathrm{K}=$ was calculated using Excel and function $\operatorname{TINV}\left(\alpha / 2 ; \mathrm{n}_{1}+\mathrm{n}_{2}-2\right)$.

The test criterion of the two-sample t-test assuming unequal variances was calculated according to the formula:

$$
T=\frac{\bar{X}_{1}-\bar{X}_{2}}{\sqrt{V_{1}+V_{2}}}
$$

Where $\bar{X}_{1}, \bar{X}_{2}$ are sample means,

$\mathrm{V}_{1}, \mathrm{~V}_{2}$ are Variance coefficients.

Critical value $\mathrm{K}=$ was calculated using Excel and function TINV $(\alpha / 2 ; n-1)$ and TINV $(\alpha / 2 ; n-1)$ (Ramík et al., 2005).

\section{Empirical research}

The research focuses on the tax knowledge of students from Bachelor and Follow-up Masters degree programmes, both full-time and part-time forms of studies. The questionnaire submission was $100 \%$ since questionnaires were distributed to respondents personally.

The questionnaire is aimed at verifying the basic tax literacy of students. Closed questions were used in the questionnaire. Questions from the area of personal income tax from employment concerns tax rates, tax allowances and tax credits. As for consumption taxation, the questions are focused only on general knowledge of selected products and tax rates.

Quantitative traits of questionnaires are stated in Table 1 and the scale rating in Table 2 .

Table 1 Quantitative traits of questionnaires

\begin{tabular}{lll}
\hline & Full-time study & Part-time study \\
\hline $\begin{array}{l}\text { Number of questionnaires - } \\
\text { Bachelor level }\end{array}$ & 357 & \\
$\begin{array}{l}\text { Number of questionnaires - } \\
\text { Follow-up level }\end{array}$ & 342 & 148 \\
$\begin{array}{l}\text { Number of identification } \\
\text { questions }\end{array}$ & 5 & 5 \\
Number of questions & 10 & 10 \\
Number of questionnaire sheets & 1 & 1 \\
\hline
\end{tabular}


Table 2 Scale ratings

\begin{tabular}{llll}
\hline Ratings & Tax knowledge & $\begin{array}{l}\text { Number of correct } \\
\text { answers }\end{array}$ & Results \\
\hline 5 & Inadequate & $0-2$ & 0 up to $19.99 \%$ \\
4 & Below average & $3-4$ & 20 up to $39.99 \%$ \\
3 & Average & $5-6$ & 40 up to $59.99 \%$ \\
2 & Very good & $7-8$ & 60 up to $79.99 \%$ \\
1 & Excellent & $9-10$ & 80 up to $100 \%$ \\
\hline
\end{tabular}

\subsection{Full-time students' knowledge}

Bachelor's degree programme students, who have not completed tax-focused subjects yet, were chosen to be respondents in the first part of the research. The aim of this research was to find out what knowledge of taxation the respondents acquired at secondary schools, family, press, or other sources.

The number of correct answers in the following graph shows the full-time students' results. There is a differentiation between bachelor degree programme students before completing their courses on tax issues and follow-up masters' degree programme students after completing the courses on tax issues, which are taught at School of Business Administration.

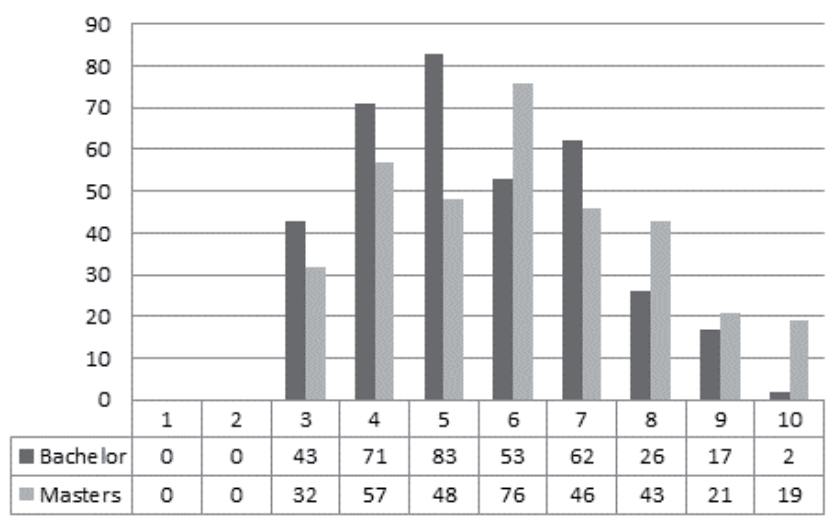

Fig. 1 Correct answers frequency of the full time students

The above graph (Fig. 1) shows that the mode for bachelor studies is 5 , but the mode for the follow-up studies is higher, specifically 6 . The number of students with all correct answers has increased from 2 bachelor degree programme students to 19 respondents in the follow-up degree programme.

According to the results in the following Table 3 it is obvious that the average results of the follow-up master degree students are better than those of bachelor one. However, they show greater variability.

$\mathrm{P}$ for F-test is less than 0.05 hence statistical significance was tested by using the two-sample t-test assuming unequal variances. As it is evident from the following Table 4, it was found that the average results of masters' students are statistically significant better than those of students in bachelor studies.
Table 3 Two-sample F-test for equal variances of full-time students

\begin{tabular}{lll}
\hline & Bachelor & Masters \\
\hline Mean & 2.9635 & 2.7625 \\
Variance s $^{2}$ & 0.7789 & 0.9346 \\
$\mathrm{P}(\mathrm{F}<=\mathrm{f})(1)$ & 0.0448 & \\
\hline
\end{tabular}

Table 4 Two-sample t-test assuming unequal variances for full-time students

\begin{tabular}{lll}
\hline & Bachelor & Masters \\
\hline Mean & 2.9664 & 2.7661 \\
Variance & 0.7798 & 0.9363 \\
Pooled Variance & 357 & 342 \\
Hypothesized Mean Difference & 0 & \\
df & 685 & \\
$\mathrm{t}$ Stat & 2.8551 & \\
$\mathrm{P}(\mathrm{T}<=\mathrm{t})(1)$ & 0.0022 & \\
$\mathrm{t}$ crit $(1)$ & 1.6471 & \\
$\mathrm{P}(\mathrm{T}<=\mathrm{t})(2)$ & 0.0044 \\
$\mathrm{t}$ crit $(2)$ & 1.9634 \\
\hline
\end{tabular}

\subsection{Extramural students knowledge}

The number of correct answers in the following graph shows extramural students' results, and again separately for bachelor and follow-up masters studies.

It is apparent from the following graph (Fig. 2) that the mode for bachelor studies is 4 , but the mode for follow-up studies is higher, specifically 9 . The number of students with all correct answers has increased from 4 bachelor degree programme students to 6 respondents in the follow-up degree programme.

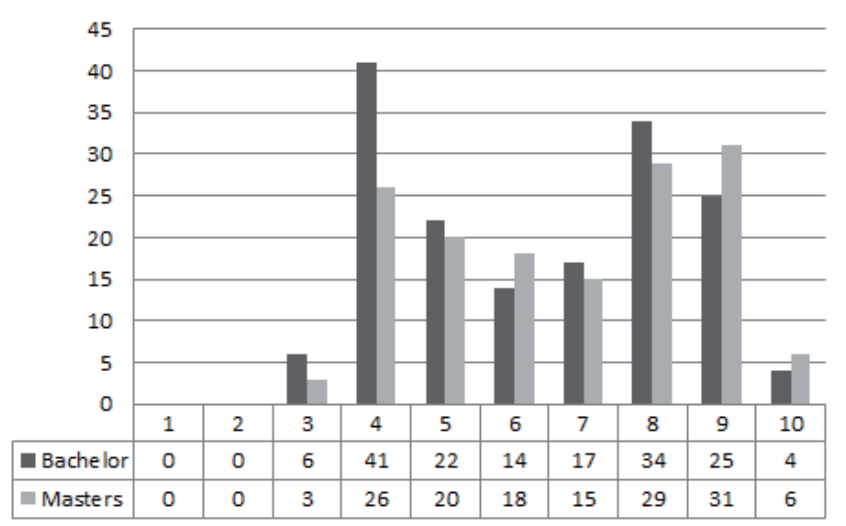

Fig. 2 Correct answers frequency of the extramural students

According to the results in the following Table 5 it is clear that the average results of the follow-up students are better than those of bachelor studies. Moreover, they show lower variability. 
Table 5 Two-sample F-test for equal variances of extramural students

\begin{tabular}{lll}
\hline & Bachelor & Masters \\
\hline Mean & 2.6111 & 2.3878 \\
Variance s $^{2}$ & 1.1708 & 1.1294 \\
$\mathrm{P}(\mathrm{F}<=\mathrm{f})(1)$ & 0.4131 & \\
\hline
\end{tabular}

$\mathrm{P}$ for F-test is higher than 0.05 hence statistical significance was tested by using the two-sample t-test assuming equal variances. As it is apparent from the following Table 6, it was found that the average results of follow-up students are not statistically significant better than those of students in bachelor studies.

Table 6 Two-sample t-test assuming equal variances for extramural students

\begin{tabular}{lll}
\hline & Bachelor & Masters \\
\hline Mean & 2.6196 & 2.3986 \\
Variance & 1.1754 & 1.1393 \\
Observation & 163 & 148 \\
Pooled Variance & 1.1582 & \\
Hypothesized Mean Difference & 0 & \\
df & 309 & \\
$\mathrm{t}$ Stat & 1.8084 & \\
$\mathrm{P}(\mathrm{T}<=\mathrm{t})(1)$ & 0.0358 \\
$\mathrm{t}$ crit $(1)$ & 1.6498 \\
$\mathrm{P}(\mathrm{T}<=\mathrm{t})(2)$ & 0.0715 \\
$\mathrm{t}$ crit $(2)$ & 1.9677 & \\
\hline
\end{tabular}

\subsection{Verification of the hypothesis}

To verify whether there is a relationship between respondents' achieved results and the form of study, the null hypothesis $\mathrm{H}_{0}$ was determined: The level of students' input knowledge concerning tax issues does not depend on the form of study they have enrolled. It means that it was checked whether respondents' differences in frequency in each group are merely coincidental, or whether there is a statistical dependence between them. In the following Tables 7 and 8, observed and expected frequencies are stated.

Table 7 Observed frequecies

\begin{tabular}{lllll}
\hline & D & C & B & A \\
\hline Full time & 114 & 136 & 88 & 19 \\
Extramural & 47 & 36 & 51 & 29 \\
\hline
\end{tabular}

Table 8 Expected frequencies

\begin{tabular}{lllll}
\hline & $\mathrm{D}$ & $\mathrm{C}$ & $\mathrm{B}$ & $\mathrm{A}$ \\
\hline Full time & 110.5327 & 118.0846 & 95.42885 & 32.95385 \\
Extramural & 50.46731 & 53.91538 & 43.57115 & 15.04615 \\
\hline
\end{tabular}

Based on calculations in the following Tables 9 and 10, it is possible to state that we reject the null hypothesis. Identified knowledge depends on the form of study the students have enrolled.

Table 9 CHI-SQUARE calculation

\begin{tabular}{lllll}
\hline (Eij-Oij) $/$ Eij & D & C & B & A \\
\hline Full time & 0.108766 & 2.718059 & 0.578313 & 5.908561 \\
Extramural & 0.238218 & 5.95305 & 1.266612 & 12.94084 \\
\hline
\end{tabular}

Table 10 CHI-SQUARE test

\begin{tabular}{ll}
\hline CHI-SQUARE & 29.71241776 \\
alpha & 0.05 \\
df & 3 \\
CHINV & 7.814727764 \\
CHIDIST & $1.58628 \mathrm{E}-06$ \\
\hline
\end{tabular}

This result is mainly influenced by the fact whether the students are employed or not. In the group of full-time students there were only $5 \%$ of employed respondents. On the contrary, in the group of part-time students there were $76 \%$ employed respondents.

\section{Conclusion}

Financial literacy of each citizen should also involve knowledge of tax issues. Taxes represent an area that every citizen daily encounters, whether they are indirect taxes, which are included in prices, or direct taxes relating to employed citizens and entrepreneurs.

Everyone should have a basic understanding of the system and form of taxation, and an overview of what tax and what amount of tax they normally pay. The problem with the Czech tax system is its complexity and opacity which allows to raising some taxes unobtrusively. Achieving and maintaining the basic tax literacy is further complicated by frequent changes in tax legislation. If a taxpayer (citizen) understands problems of taxation, it helps them take advantage of tax optimization and reduce their tax base, and thereby the final tax by claiming tax credits, tax deductions, and tax benefits. 
The level of students after completing the courses on tax issues has improved both in full-time and part-time forms of study. In case of full-time study, it was demonstrated that average results in follow-up studies are statistically significant better than those in bachelor studies. However, in contrast to this, statistical significance was not demonstrated in case of extramural students although follow-up masters students were achieving better average results even here.

On the basis of the research, it was identified and verified statistically that students, who enrol on extramural form of study, have a better knowledge of tax issues. Knowledge differences among extramural and part-time students are influenced by the fact that unlike full-time students, most extramural students have a job.

With respect to variability it is obvious that the chosen form of study may have an impact on the individual student's knowledge. In case of extramural form of study, where teaching takes the form of expert tutorials, the main workload is based on students themselves. Then the variability is more affected by an individual student's approach with a greater emphasis on individual work. Full-time students can further enhance their knowledge, gained during lectures, in seminars including ongoing consultations with lecturers.

\section{Acknowledgement}

This paper was supported by the Ministry of Education, Youth and Sports Czech Republic within the Institutional Support for Long-term Development of a Research Organization in 2015.

\section{References}

Barjoyai, B. (1992) Tax Illiteracy in Malaysia: Problems Solutions. Journal of ACCAMADIA. 2(2), pp. 7-31.

Blechová, B. (2012) Progresivní nebo „rovná“ daňekonomické a politické dilema. (Progressive or "Flat" Tax-Economic and Political Dilemma.) Politická ekonomie. 60(5), pp. 649-668. (in Czech)

Blechová, B., Sobotovičová, Š. (2013) Daňová vzdělanost jako součást finanční gramotnosti. (Tax Education as a Part of Financial Literacy.) Trendy ekonomiky a managementu. 7(14), pp. 17-24. (in Czech)

Boccanfuso, D., Larouche, A., Trandafir, M. (2015) Quality of Higher Education and the Labor Market in Developing Countries: Evidence from an Education reform in Senegal. World Development. 74, pp. 412-424. DOI: 10.1016/j.worlddev.2015.05.007

Csongor, S. (2011) Financial Literacy and Self-care in Hungary. Management Agricol. 13(1), pp. 311-318.

Disney, R., Gathergood, J. (2013) Financial literacy and consumer credit portfolios. Journal of Banking \& Finance. 37(7), pp. 2246-2254. DOI: 10.1016/j.jbankfin.2013.01.013

Eriksen, K., Fallan, L. (1996) Tax knowledge and attitudes towards taxation; A report on a quasi-experiment. Journal of Economic Psychology. 17(3), pp. 387-402. DOI: 10.1016/0167-4870(96)00015-3

Chardon, T. (2014) Taxation and superannuation literacy in Australia: what do people know (or think they know)? JASSA. 1, pp. 42-48.

Gillen, M., Loeffler, D. N. (2012) Financial literacy and social work students: Knowledge is power. Journal of Financial Therapy. 3(2), pp. 28-38. DOI: $10.4148 /$ jft.v3 i2.1692
Hadi, R.,Wahyudin, U., Ardiwinata, J. S., Abdu, W. J. (2015) Education and microfinance: an alternative approach to the empowerment of the poor people in Indonesia. SpringerPlus. 4(1), p. 244.

DOI: 10.1186/s40064-015-0995-6

Hammer, S. J., Chardon, T., Collins, P., Hart, C. (2012) Legal educators perceptions of lifelong learning: Conceptualisation and practice. International jurnal of Lifelong Education. 31(2), pp.187-201.

DOI: 10.1080/02601370.2012.663803

Janoušková, J. (2011) Daně a daňová politika: osobní důchodová daň. (Taxes and tax policy: Personal income tax.) Slezská univerzita v Opavě, OPF v Karviné, Opava. (in Czech)

Janoušková, J., Sobotovičová, Š. (2013a) Daňová vzdělanost v kontextu širších souvislostí edukačního procesu. (Tax Education in the Context of the Broader Coherence of the Educational Process.) In: Vaněk, J. (ed.): Rozvoj kličových kompetenci pracovníků vysokých škol. (The Development of Key Competencies of University Staff.) Slezská univerzita v Opavě, OPF v Karviné, Opava. pp. 116-123. (in Czech)

Janoušková, J., Sobotovičová, Š. (2013b) Distortion in Taxation of Wages. In: Finance and the performance of firms in science, education, and practice. Zlín, Univerzita Tomáše Bati. pp. 290-301.

Kamaluddin, A., Madi, N. (2005) Tax literacy and Tax awareness of Salaried Individuals in Sabah and Sarawak. Journal of Financial Reporting and Accounting. 3(1), pp. 71-89. DOI: 10.1108/19852510580000338

Kindle, P. A. (2010) Student perceptions of financial literacy: Relevance to practice. Journal of Social Service Research. 36(5), pp. 470-481. DOI: $10.1080 / 01488376.2010 .510951$

Kucharčíková, A. (2014). Investment in the human capital as the source of economic growth. Periodica Polytechnica Social and Management Sciences. 22(1), pp. 29-35. DOI: 10.3311/PPso.7426

Madi, N., Kamaluddin, A., Janggu, T., Ibrahim, M. B. A., Samah, A. B. A., Jusoff, K. (2010) Tax literacy among employees: Sabah and Sarawak's perspective. International Journal of Economics and Finance. 2(1), pp. 218-223. DOI: 10.5539/ijef.v2n1p218

Natrah, S. (2014) Tax Knowledge, Tax Complexity and Tax Compliance: Taxpayers' View. Procedia - Social and Behavioral Sciences. 109, pp. 10691075. DOI: 10.1016/j.sbspro.2013.12.590

Paseková, M., Ředinová, H., Oprean, V., Kallaste, K., Homolka, L., Blechová, B., Sobotovičová, Š. (2013) The level of financial literacy among the high school students in the chosen regions of the Czech Republic. International Journal of Mathematical Models and Methods in Applied Sciences. 7(4), pp. 462-469.

Ramík, J., Stoklasová, R., Tošenovský, J. (2005) Statistické metody pro economy, distanční studijní opora. (Statistical Methods for Economists.) Slezská univerzita v Opavě, OPF v Karviné, Opava. (in Czech)

Ramík, J., Perzina, R. (2014) Microsoft Excel as a Tool for Solving Multicriteria Decision Problems. Procedia Computer Science. 35, pp. 1455-1463. DOI: 10.1016/J.PROCS.2014.08.206

Tokarčíková, E., Kucharčíková, A., Durišová, M. (2015) Education of Students of the Study Program Informatics in the Field of Corporate Social Responsibility. Periodica Polytechnica Social and Management Sciences. 23(2), pp. 106-112. DOI: 10.3311/PPso.7473

Vybíhal, V. a kol. (2011) Slabikář Finančni gramotnosti. (Financial Literacy Primer) 2nd updated edition, COFET, a.s., Praha. (in Czech)

Yilmaz, H. (2011) Improving Financial Literacy: The U.S Experience. International Journal of Business and Social Science. 2(11), pp. 65-72. 